\title{
Study of Oxidative Stress and Genotoxicity by Arsenic Contamination in Glycine max. L
}

\author{
Silvana Mariel Marsa1, Franco R. Rossi ${ }^{2}$, Hugo A. Valdez ${ }^{2}$, \\ Diego F. Gomez-Casati ${ }^{3}$ and Fanny Zirulnik ${ }^{1^{*}}$ \\ ${ }^{1}$ Laboratorio de Química Biológica. Proyecto 2-3814, Facultad de Química, Bioquímica y Farmacia, \\ Universidad Nacional de San Luis, Ejército de los Andes 950, 5700- San Luis, Argentina. \\ ${ }^{2}$ Instituto de Investigaciones Biotecnológicas- Instituto Tecnológico de Chascomús (IIB-INTECH), \\ CONICET/UNSAM, Chascomús, Argentina. \\ ${ }^{3}$ Centro de Estudios Fotosintéticos y Bioquímicos (CEFOBI), Universidad Nacional de Rosario, \\ Argentina.
}

\section{Authors' contributions}

This work was carried out in collaboration between all authors. Author FZ designed the study, wrote the first draft of the manuscript and managed the literature searches. Authors SMM and FRR performed the anatomical, biochemical and cytogenetic analysis. Authors SMM, HAV and DFGC performed the molecular determinations. All authors read and approved the final manuscript.

Article Information

DOI: $10.9734 / I J P S S / 2015 / 18979$

Editor(s):

(1) Marco Trevisan, Institute of Agricultural Chemistry and Environmental Research Centre BIOMASS, Faculty of Agriculture, Catholic University of the Sacred Heart, Italy. Reviewers:

(1) Anonymous, Rajiv Gandhi University of Knowledge Technologies (RGUKT), India. (2) Bhaskar Sharma, Department of Biochemistry, Suresh Gyan Vihar University, India. Complete Peer review History: http://sciencedomain.org/review-history/10034

Original Research Article

Received $19^{\text {th }}$ May 2015

Accepted $18^{\text {th }}$ June 2015

Published $4^{\text {th }}$ July 2015

\section{ABSTRACT}

Introduction: Volcanism is an important natural origin of Arsenic (As) contamination.

Aims: Oxidative stress parameters, antioxidant defense system, the expression of transcripts involved in defense responses and the As genotoxicity were analyzed.

Study Design: The plants were separated into two groups (Control and As-treated ones) until they were exposed to As (2.5 and $5 \mathrm{ppm})$ at day 10 .

Methodology: Biochemical, molecular and cytogenetic determinations were carried out.

Results: Arsenic treated plants show growth abnormalities. The antioxidant defenses and oxidative parameters in roots and leaves showed different tissue-specific responses. Whereas leaf tissues display an active antioxidant defense, root cells are unable to produce defense molecules and 
show oxidative stress. Moreover, the analysis of antioxidant enzymes such as ascorbate peroxidase and superoxide dismutase, showed higher activity in leaves than in roots, except for isocitrate dehydrogenase. The expression of GR and MAPK decreased significantly in all the treatments during the time curve. ICDH showed an increase in its expression with 24 hours of treatment and falls at 72 hours compared to their controls. Genotoxicity assays showed a decrease of mitotic index (MI) and the presence of altered nucleus, in samples exposed for 72 hours.

Conclusion: Our results suggest that the physiological, biochemical, molecular and cytogenetic behavior of the plants depends on the As concentration and the length of the exposure.

Keywords: Arsenic; soybean; oxidative stress; antioxidant defenses; genotoxicity.

\section{ABBREVIATIONS}

As, arsenic; DTNB, 5, 5'- dithiobis (2-nitrobenzoic acid); GR, Glutathione Reductase; GSH, Reduced glutathione; GSSG, Oxidized glutathione; $\mathrm{H}_{2} \mathrm{O}_{2}$,Hydrogen peroxide; MDA, Malondialdehyde; NBT, Nitroblue Tetrazolium; MI, Mitotic Index.

\section{INTRODUCTION}

Arsenic (As) is present in many environments and becomes a highly toxic compound for all forms of life. The high levels of As in the soil produce considerable concern due to its incorporation by plants and the subsequent intake by humans and animals. There are several chemical forms of arsenic in the environment, including organic and inorganic molecules. It has been described that the toxicity of this metal depends on its chemical form. In general, the inorganic species arsenite As (III) and arsenate As (V), which are the bioavailable forms in soils, are more toxic than the arsenicderived organic compounds [1]. In addition, there is also an interconversion between species regulated by biotic and abiotic factors [2]. Previously, it has been reported that As (III) is usually complexed with phytochelatins [3]. This is an important mechanism commonly used by plants to reduce the As (III) mobility and its detoxification [4]. On the other hand, As (V) acts as a phosphate analogue and is translocate through the plasma membrane mediated by $\mathrm{Pi}$ cotransporters [5]. Once inside the cytoplasm, As (V) competes with $\mathrm{Pi}$, replacing the ATP to form unstable ADP-As, interfering with essential cellular processes such as oxidative phosphorylation and ATP synthesis and thus, leading to disruption of the energy flow within cells [6-8]. Inorganic arsenic species, as well as other heavy metals, produce oxidative stress by generating Reactive Oxygen Species (ROS) [8]. These species react with several biomolecules, including lipids, proteins, pigments and nucleic acids, causing lipid peroxidation, membrane damage, enzyme inactivation and DNA fragmentation, leading to a decrease in cell viability [9]. Photosynthetic organisms possess a strong antioxidant defense system to tolerate high concentration of metals. This system involves several enzymes and low molecular weight compounds which are mainly constitutive and play an important metabolic role at the cellular and subcellular level [10]. It has been reported that two of the components of this antioxidant defense system; ascorbate and glutathione are increased by the arsenic induced stress. In addition, plants exposed to As show an increase of the synthesis of phytochelatins, the polymers of glutathione [7]. Reduced Glutathione (GSH) protects proteins against denaturation caused by the oxidation of protein thiols groups during stress. It has been reported that the Reduced Glutathione/ Oxidized Glutathione (GSH/GSSG) couple is a redox sensor indicative of the general cellular thiol- disulphide redox balance, acting as a signaling component during development, abiotic stress or pathogen attack $[10,11]$. The effects of GSH on Arabidopsis roots and the results of Kerk and Feldman [12] indicate that the couple GSH/GSSG could act as sensor and effector providing a direct link between environmental stress and the morphological adaptations to alterations in the pattern of cell division in the apical meristem of the taproot [13]. To detect the genotoxic effects of As, preparations with meristematic root tip cells were observed under microscope and the results were expressed as Mitotic Index (MI), [14]. Donglin Guo et al. [15] investigate the relationship between the induction of genotoxicity and the production of free radicals in young seedlings of $V$. faba exposed to nitrobenzene. Their results indicate that reactive oxygen species may 
contribute to genotoxicity. Trivalent and pentavalent forms of arsenic have been shown to induce programmed cellular death (PCD) in plants and apoptosis in human beings [16-18]. In addition, Ramirez et al. [19] and Shi et al. [20], observed induction of chromosome/ chromatid breaks or exchanges (clastogenicity) in cultured human cells and DNA-protein cross links, chromosomal aberrations in keratinocytes, respectively. Duquesnoy et al. [21] study the potential biochemical and genotoxic effects of arsenic on plants. They observed that As contamination produced alterations on the growth and activity of the enzymatic antioxidant system and on the mitotic index (MI) and micronucleus (MN) in roots of $Z$. mays and $V$. faba. The objective of this study was to analyze the relationship between antioxidant defenses, oxidative stress and PCD on soybean seedlings under As contamination. For this purpose, we analyze different oxidative stress compounds, the enzymatic and non-enzymatic antioxidant defense system, and the expression of transcripts involved in defense responses after the exposure of soybean plants to As. Moreover through the measurement of the mitotic index the genotoxicity of As was determined.

\section{MATERIALS AND METHODS}

\subsection{Plant Material and Growing Conditions}

Glycine max. L. seeds were sterilized with $2.5 \%$ V/V sodium hypochlorite before they were potted and allowed to grow under hydroponic conditions in a controlled greenhouse $\left(24 \pm 2^{\circ} \mathrm{C}, 50 \%\right.$ of relative humidity and a photoperiod of $16 \mathrm{~h}$ with a photon flux density of $280 \mu \mathrm{mol} \mathrm{m} \mathrm{m}^{-2} \mathrm{~s}^{-2}$ ). The plants were supplied every $48 \mathrm{~h}$ with Hoagland nutrient solution [22], and separated into two groups (Control and As-treated ones) until they were exposed to As (2.5 and $5 \mathrm{ppm}$ ) at day 10 . The experiment was in a completely randomized design with six replicates over two independent experiments. Leaves and roots were processed and assayed for $24 \mathrm{~h}$ and $72 \mathrm{~h}$ in Control and As supplied plants, respectively.

\subsection{Arsenic Determination}

The As content ( $\left.\mu \mathrm{mol} \mathrm{g}^{-1} \mathrm{DW}\right)$ in leaves and roots was measured by an inductively coupled plasma mass spectrometer (ICP-MS), PerkinElmer SCIEX, ELAN DRC-e (Thornhill, Canada) and referred to Dry Weight (DW). Total As levels were validated as previously described [23].

\subsection{Glutathione, Non-protein Thiols and Phytochelatins Determination}

Reduced glutathione (GSH) and non-protein thiols (NPT) were extracted by homogenizing $250 \mathrm{mg}$ of roots and leaves in $2 \mathrm{ml} 0.1 \mathrm{~N} \mathrm{HCl}$, $1 \%(\mathrm{w} / \mathrm{v})$ polyvinylpyrrolidone (PVP), and $10 \mathrm{~min}$ centrifugation at $10,000 \times g$ at $4^{\circ} \mathrm{C}$ [24]. The GSH content was estimated by incubating $100 \mu$ l of the supernatant with buffer phosphate $(0.5 \mathrm{M}$ $\left.\mathrm{KH}_{2} \mathrm{PO}_{4} / \mathrm{K}_{2} \mathrm{HPO}_{4}\right), 1 \mathrm{~g} / \mathrm{l}$ ascorbic acid and $0.5 \mathrm{~g} / \mathrm{L}$ glyoxylic acid, $\mathrm{pH} 6.8$, for $5 \mathrm{~min}$ at $60^{\circ} \mathrm{C}$, and then quickly cooled on ice. After this, $100 \mu \mathrm{l}$ of Ellman reagent $(6 \mathrm{mM}$ DTNB, $50 \mathrm{mM}$ potassium phosphate buffer, $\mathrm{pH} 7.4$ ) was added to each tube, mixed and centrifuged at $12,000 \times \mathrm{g}$ for 2 min (minifuge), and the OD412 $\mathrm{nm}$ was determined. Controls containing the buffer solution and different GSH amounts were prepared from a ${ }^{4} \mathrm{mM}$ GSH stock and diluted 1:10. Results were expressed as $\mu$ moles $\mathrm{SH}$ g-1 FW [25]. To determine NPT contents, $200 \mu$ of the supernatant was mixed with phosphate buffer (0.5 $\mathrm{M} \mathrm{KH}_{2} \mathrm{PO}_{4} / \mathrm{K}_{2} \mathrm{HPO}_{4}, 1 \mathrm{mM}$ EDTA, $\mathrm{pH}$ 8) and $100 \mu \mathrm{l}$ Ellman reagents were added to start the reaction. The OD412 $\mathrm{nm}$ was measured after the incubation of the samples for $15 \mathrm{~min}$ at $30^{\circ} \mathrm{C}$, and corrected to the DTNB/ no enzyme control [26]. Phytochelatins (PC) content were estimated by the difference between total non-protein $\mathrm{SH}$ and GSH levels as reported previously [27].

\subsection{Hydrogen Peroxide Quantification}

$\mathrm{H}_{2} \mathrm{O}_{2}$ concentrations were determined according to Sergiev et al. [28]. Samples were homogenized with $2 \mathrm{ml} 0.1 \%(\mathrm{w} / \mathrm{v})$ trichloroacetic acid (TCA) (Merck, USA). The homogenate was centrifuged at $12,000 \times g$ for $15 \mathrm{~min}$, and $0.5 \mathrm{ml}$ of the supernatant was added to $0.5 \mathrm{ml} 10 \mathrm{mM}$ potassium phosphate buffer $(\mathrm{pH} 7.0)$ and $1 \mathrm{ml}$ $1 \mathrm{M}$ potassium iodide $(\mathrm{KI})$ and the OD390 $\mathrm{nm}$ was determined. Controls were prepared by adding 1 $\mathrm{ml}$ of $10 \mathrm{mM}$ potassium phosphate buffer $(\mathrm{pH}$ 7.0) instead of the sample.

\subsection{Determination of Lipid Peroxidation}

Lipid peroxidation was determined according to Heath and Packer [29] as the amount of malondialdehyde (MDA) obtained from the thiobarbituric acid (TBA) reaction. Briefly, after 24 and $72 \mathrm{~h}$ of exposure to As, $250 \mathrm{mg}$ of leaves and roots were homogenized in $5 \mathrm{ml}$ of $0.1 \%$ (w/v) Trichloroacetic Acid (TCA) and centrifuged at $10,000 \times g$ for $20 \mathrm{~min}$; the same procedure 
was applied to control leaves and roots. Supernatants were mixed at equal volumes with $20 \%(\mathrm{w} / \mathrm{v})$ TCA containing $0.5 \%(\mathrm{w} / \mathrm{v})$ TBA, incubated $95^{\circ} \mathrm{C}$ for $30 \mathrm{~min}$ and immediately cooled on ice. The homogenates were centrifuged at $10,000 \times \mathrm{g}$ for $15 \mathrm{~min}$ and OD532 $\mathrm{nm}$ was determined. The concentration of MDA was calculated using an extinction coefficient of $155 \mathrm{mM}^{-1} \mathrm{~cm}^{-1}$.

\subsection{Enzyme Assays}

Homogenates were prepared from $250 \mathrm{mg}$ of frozen As-treated and control leaves and roots. The extracts were obtained by grinding the plant tissues in liquid nitrogen using mortar and pestle and $2 \mathrm{ml}$ extraction buffer, composed by $50 \mathrm{mM}$ Tris- $\mathrm{HCl}$ ( $\mathrm{pH}$ 7.4), $1 \mathrm{mM}$ EDTA, $1 \mathrm{~g}$ PVP, $10 \mathrm{mM}$ $\mathrm{MgCl}_{2}$ and $2 \mathrm{mM}$ DTT. The homogenates were centrifuged at $10,000 \times g$ for $20 \mathrm{~min}, 4^{\circ} \mathrm{C}$, and supernatants were used for different enzyme assays. NADP- isocitrate dehydrogenase (ICDH) (EC 1.1.1.42) activity was measured spectrophotometrically by following the NADP reduction at $340 \mathrm{~nm}$ in $100 \mathrm{mM}$ Tris- $\mathrm{HCl}$ buffer (pH 7.5), which contained $5 \mathrm{mM} \mathrm{MgCl}_{2}$, and 0.1 mM NADP, as described previously by Chen et al. [30]. After equilibration at $30^{\circ} \mathrm{C}$, the reaction was started by adding $2 \mathrm{mM}$ isocitrate. One unit of activity is defined as the production of $1 \mathrm{nmol}$ $\mathrm{NADPH} \mathrm{min}^{-1} \mathrm{mg}^{-1}$ protein. Homogenates for the determination of SOD (EC 1.15.1.1) activity were prepared from $250 \mathrm{mg}$ of leaves and roots grinded under ice-cold conditions using $1 \mathrm{ml}$ of extraction buffer (50 mM phosphate buffer, $1 \mathrm{mM}$ EDTA, 0, $1 \mathrm{~g}$ PVP and 0.5\% (v/v) Triton X-100, $\mathrm{pH}$ 7.4). Homogenates were centrifuged at $10.000 \times \mathrm{g}$ for $20 \mathrm{~min}$, and the supernatant fraction was used for assays. SOD activity was measured spectrophotometrically as described by Beyer and Fridovich [31]. One unit of SOD activity is defined as the amount of enzyme producing a $50 \%$ inhibition of the photochemical reduction of nitro blue tetrazolium (NBT). The specific activity of SOD was expressed as Umg- ${ }^{1}$ of protein. Total ascorbate peroxidase (APX) (EC 1.11.1.11) activity was determined from the decrease in OD290 $\mathrm{nm}$ resulting from the $\mathrm{H}_{2} \mathrm{O}_{2}$ dependent oxidation of ascorbate $(\varepsilon 290=2.8$ $\mathrm{mM}^{-1} \mathrm{~cm}^{-1}$ ) [32]. The reaction mixture contained $50 \mathrm{mM}$ potassium phosphate $(\mathrm{pH} 7.5), 0.5 \mathrm{mM}$ ascorbate, $0.1 \mathrm{mM} \mathrm{H}_{2} \mathrm{O}_{2}$ and protein extract (final volume $=1 \mathrm{ml}$ ) at $25^{\circ} \mathrm{C}$. One unit of the enzyme activity is defined as the amount oxidizing $1 \mu \mathrm{mol}$ of ascorbate $\mathrm{min}^{-1}$.

\subsection{Protein Determination}

Protein concentration was determined spectrophotometrically according to Bradford [33], using bovine serum albumin as the standard.

\subsection{RNA Extraction and RT-PCR}

Roots and leaves were harvested after 24 and 72 $\mathrm{h}$ of exposure to As (2.5 and $5 \mathrm{ppm}$ ) from 10days old seedlings. Seedlings that were not exposed to As were used as controls. RNA was extracted by using the SV Total RNA Isolation Kit System [34]. cDNA was synthesized with random hexamers using reverse transcriptase (Life technologies). cDNA was submitted to 20 cycles of PCR amplification using the following primers: a) Primers soybean actin: Forward 5' ACGAGCCCTAGCATTGTGG 3', Reverse 5' AACCGTCCCGCACCGATA 3'. b) Primers MAPK1: $\quad$ Forward 5 TTGCTCGCTGTTGAATACCGAG 3', Reverse 5 ' ATAGCAGAGGTGTAATCAGAGGAAT $3^{\circ}$. c) Primers GR: Forward 5'CTACGGCGCTTCTGTCGC 3'. Reverse 5'ATCAACCGTGTGAGGATCTATCAT C 3'. d) Primers ICDH: Forward: 5'GATGATATGGTGGCGTATGC 3', Reverse: 5' GGCTGCTTCTGCTTCAATAG 3'. PCR products were analyzed on agarose gels and visualized using ethidium bromide.

\subsection{Genotoxicity Assays}

The germination was carried out by placing the seeds at $22^{\circ} \mathrm{C}$ in darkness for 96 hours, then the tips of the roots were submerged in hydroponics solution with 2.5 and 5 ppm of As for 24 and 72 hours at the same temperature, in darkness and the corresponding controls were performed. The apexes were cut and fixed in Carnoy (absolute ethanol: glacial acetic acid, 3:1), for $10 \mathrm{~min}$. The "squash" and stained was performed with a solution of $2 \%$ acetic carmine and sealing the edges with nail polish to prevent cellular dehydration. Each preparation was observed with an optical microscope with 100X objective (immersion) and photographs were taken with a Sony camera microscope adapter. Photos from a) to e) correspond to phases observed in both treated and control samples taken at random from a total of 300 cells counted for each batch (Control 24, TI 24, TII 24, Control 72, TI 72 and TII 72). The normal phases of mitosis and the presence of alterations were documented with photographs. The different cellular cycle phases 
were counted and identified. With the obtained values, the mitotic index was estimated as the percentage of dividing cells in a tissue and, therefore, it is a measure of the proliferative potential of the cellular cycle. In all cases, the presence of nuclear abnormalities was search for and recorded, using the photographs [35]. The mitotic index was calculated as: $\mathrm{Ml}=$ Number of mitosis X 100 / Total number of cells.

\subsection{Statistical Analyses}

Mean values were obtained from six replicates $(n=6)$ over 3 independent experiments, (each replicate is a pool composed by 3 different plants at least). Prior to statistical analyses, the normality of the data was tested by KolmogorovSmirnov test. In all the cases, the variances were homogeneous. Data were analyzed by one-way ANOVA, and the treatment mean values were compared by post-hoc Tukey- Kramer test at $P<$ 0.05 .

\section{RESULTS}

\subsection{Concentration of Arsenic Levels in Different Tissues of Glycine max. L}

We found different amounts of As values in leaves and roots of soybean plants and they were expressed as parts per billion (ppb). In all cases the determinations were made by duplicate and expressed as average value thereof. The higher values of As were found in roots (200- $300 \mathrm{ppb}$ ), while its concentration was lower in leaves (13- $26 \mathrm{ppb}$ ).

\subsection{Study of Anatomical Parameters}

Treatment with $2.5 \mathrm{ppm}$ of As (TI) and $5 \mathrm{ppm}$ ( $\mathrm{T}$ II) for $24 \mathrm{~h}$ produce a decrease in the fresh weight of the leaves samples when compared to control plants, while there were no significant differences in roots at $24 \mathrm{~h}$ (Fig. 1, black bars). Therefore, the total fresh weight values, comprising the sum of the two evaluated parameters, are greatly diminished with $72 \mathrm{~h}$ of treatment (Fig. 1, grey bars). In the treated samples using both As concentrations there was a marked decrease in the fresh weight of leaves after $72 \mathrm{~h}$, in which a high degree of dehydration is observed. The fresh weight of roots did not show any significant differences in samples with $T$ II because the length of the taproot increases while the secondary roots decrease in length and number (Photo 1). Plant growth decreases both for $\mathrm{T} \mathrm{I}$ and $\mathrm{T}$ II at 24 and $72 \mathrm{~h}$ (Photo 1). These results are in agreement with the measurements of main root and stem length, which did not show any significant difference in the presence of As, but a significant decrease was shown at $24 \mathrm{~h}$ with $\mathrm{T}$ I and $\mathrm{T}$ II when total length was determined (Fig. 2, black bars). Stems and total length of the plants was measure and a decreased in all cases was observed with $72 \mathrm{~h}$ of treatment (Fig. 2, grey bars).

\subsection{Study of Oxidative and Antioxidative Stress Parameters}

Oxidative stress parameters behaved differently in every case, in the defense response such as GSH, PC and NPT, and the products of stress itself (TBARS, $\mathrm{H}_{2} \mathrm{O}_{2}$ ), depending on the organ analyzed, roots or leaves. In the case of leaves, the amounts of GSH, NTP, PC and TBARS, increased, correlating with the increase of As concentration (2.5 and $5 \mathrm{ppm}$ ) and the exposure time is prolonged (72 h). In contrast, it was observed a marked decrease in all parameters in roots, when comparing the values obtained from the roots of treated plants to those of controls (Co) $p<0.05$ (Fig. 3). These results are higher in leaves $(90 \%)$ respect of roots. The oxidant parameters: TBARS and $\mathrm{H}_{2} \mathrm{O}_{2}$ showed a decrease of $90 \%$ in roots and the defense parameters only decrease $20 \%$.

\subsection{Quantification of Enzymes Related to Stress}

The data of enzyme catalytic activities should be analyzed on the basis that the total amount of proteins in leaves are higher than in roots, which agrees with the low values of As measured in this organ. In contrast, low levels of protein synthesis are observed in roots, where we found high values of As. It should be noted that there are no significant differences between treated samples and controls in roots, but in leaves at TII $24 \mathrm{~h}$ there was a significant increase, $\mathrm{p}<0.05$ (Fig. 4). Ascorbate peroxidase (APX) activities of leaf did not show significant difference respect to controls. In root samples there is a marked decrease of the activity of this enzyme for both treatments at 24 or $72 \mathrm{~h}$, to the extent that no activity was detected in the samples with $\mathrm{TI}$ neither for $72 \mathrm{~h}$ nor in samples with $\mathrm{T}$ II at both times, $p<0.05$. Superoxide dismutase (SOD) activity increases only in leaf samples with TII exposed for $24 \mathrm{~h}, \mathrm{p}<0.001$; the rest of the samples showed no significant difference with 
controls and in roots there were a significant decreased in all the samples, except TII $24 \mathrm{~h}, \mathrm{p}$ $<0.05$. Isocitrate dehydrogenase $(\mathrm{ICDH})$ activity in leaves increases on samples with $\mathrm{TI}$ exposed for $24 \mathrm{~h}$ and in those with $\mathrm{T}$ II exposed for $72 \mathrm{~h}, \mathrm{p}$ $<0.05$; in other samples the activity of this enzyme did not show significant differences respect to controls. In roots we observed an increase of the enzymatic activity only in the sample with $\mathrm{TI}$ exposed for $24 \mathrm{~h}, \mathrm{p}<0.01$; the other samples showed no significant difference with controls (Fig. 4).

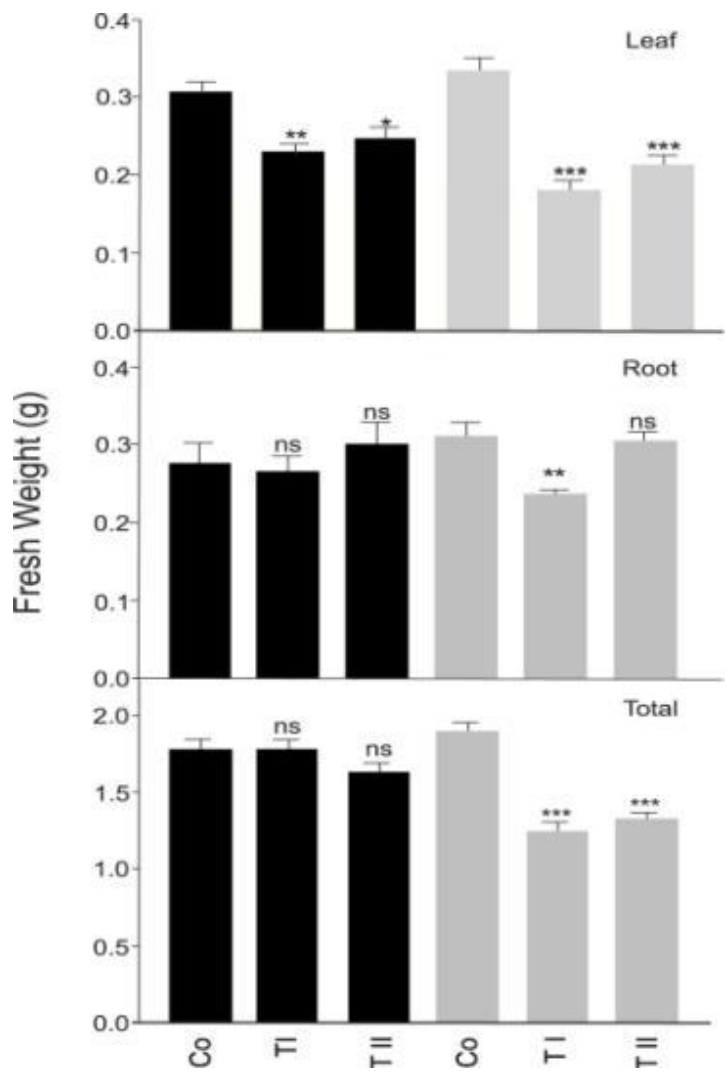

Fig. 1. Study of fresh weight in leaves, roots and total plant after different treatments

The black bars correspond to control samples and arsenic treated for $24 \mathrm{~h}$, while the grey bars correspond to a treatment of $72 \mathrm{~h}$. Co: Control, Tl: exposure to $2.5 \mathrm{ppm}$, TIl: exposure to $5 \mathrm{ppm}$. Mean values and standard error of mean (SEM).

${ }^{*} p<0.05,{ }^{* *} p<0.01,{ }^{* * *} p<0.001$, ns: no-significant

\subsection{RT-PCR Studies of Genes Involves in Stress Responses}

The expression of genes regulated during the process of oxidative stress compared with the expression of a constitutive gene such as actin was analyzed in the root. As we mentioned above, the root is the organ where a higher concentration of As was found. A decrease of two-fold in the mRNA levels of GR in treated samples was observed, which is accentuated as the exposure time to As increases. The MAPK I gene shows the same behavior, while the ICDH gene expression increases two-fold during the first $24 \mathrm{~h}$ which correlates with the increase in As concentration. In contrast, this transcript showed a significant decreased after $72 \mathrm{~h}$ of As exposure (Fig. 5).

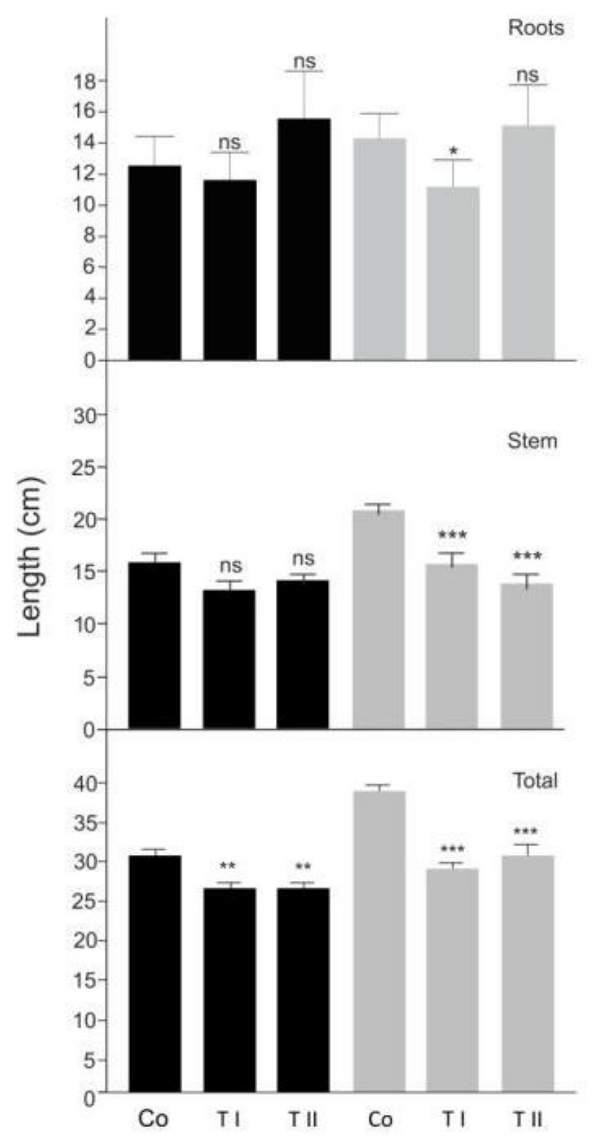

Fig. 2. Glycine max. L. length under arsenic treatment

The black bars correspond to control samples and arsenic treated for $24 h$, while the grey bars correspond to a treatment of $72 \mathrm{~h}$. Co: Control, $\mathrm{Tl}$ : exposure to $2.5 \mathrm{ppm}$, Tll: exposure to $5 \mathrm{ppm}$.

Mean values and standard error of mean (SEM)

${ }^{*} p<0.05,{ }^{* *} p<0.01,{ }^{* * *} p<0.001, n s$ : no-significant

\subsection{Mitotic Index as a Parameter of Genotoxicity}

Interphase cells were observed in all samples in both controls and treated all times (24 and $72 \mathrm{~h}$ ). With regard to the different stages of mitosis (prophase, metaphase, anaphase and telophase) 
were also observed in all samples from both controls and treated. Disorganized metaphases were observed in samples treated with $2.5 \mathrm{ppm}$ As at both 24 and at 72 hours. The anomalies (fragmented nucleus, micronucleus, binucleated cells) were observed only in the sample treated with $2.5 \mathrm{ppm}$ As for $72 \mathrm{~h}$. There were no differences of the Ml values between control and treated samples at different concentrations of As at 24 hours. However, the samples exposed for 72 hours showed a decreased MI (Table 1). Photo 2: It can be observed clastogenic effects and appearance of altered cells in this group of treated samples: a)interphase Co, 24h; b) prophase at sample treated with $2,5 \mathrm{ppm}$ As (T I) at $24 \mathrm{~h}$; c) metaphase $\mathrm{Co}, 72 \mathrm{~h}$; d) anaphase treated sample with $5 \mathrm{ppm}$ As (TII) $72 \mathrm{~h}$; e) telophase treated sample with $2.5 \mathrm{ppm}$ As (TI) $72 \mathrm{~h}$; f) micronuclei treated sample $2.5 \mathrm{ppm}$ As (TI) $72 \mathrm{~h} ; \mathrm{g}$ ) disordered metaphase treated sample with 2.5ppm As 24 and $72 \mathrm{~h}$; h) binucleated cells and i) fragmented nuclei treated sample with $2.5 \mathrm{ppm}$ As $72 \mathrm{~h}$.

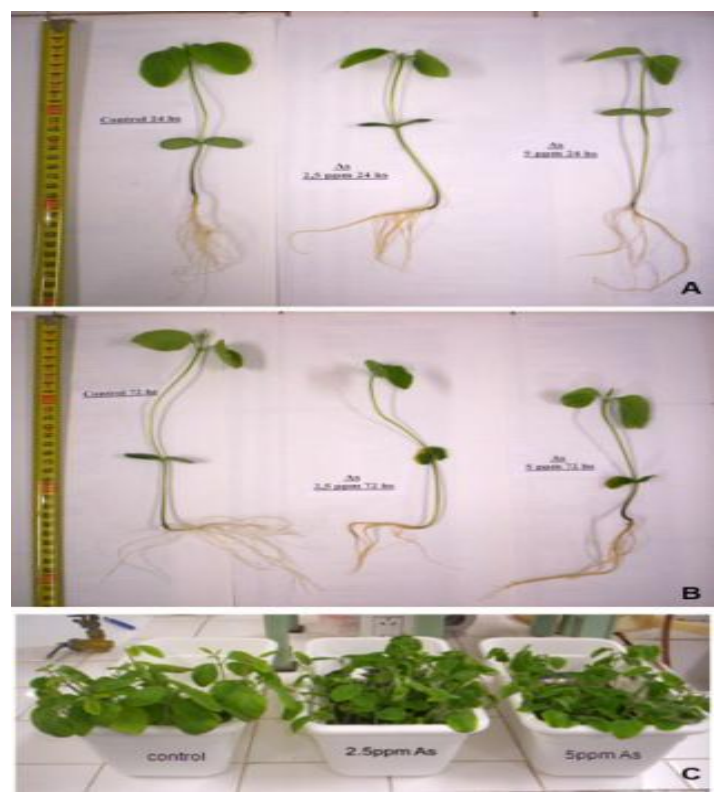

Photo 1. Morphological changes in Glycine max. L

Control, As treatment with $2.5 \mathrm{ppm} 24 \mathrm{~h}$ and $5 \mathrm{ppm}$ 24 and $72 h$

\section{DISCUSSION}

Arsenic (As) generates oxidative stress and consequently soybean plants undergo morphological and biochemical changes and also modifies the expression of many genes. The study of the effect of As on soybean plants, focusing on the stress induced by this compound, is of great interest in order to understand the yield reduction of this crop in areas with high pollution. Plants can incorporate arsenic through different organs such as roots and leaves and its translocation has been studied in some species [36]. Generally, after a term exposure to large amounts of root arsenic, plants fail to grow and develop [36-39]. In this study we used those arsenic concentrations reported by several investigations in places as the south of the provinces of San Luis and Córdoba, Argentina [40].

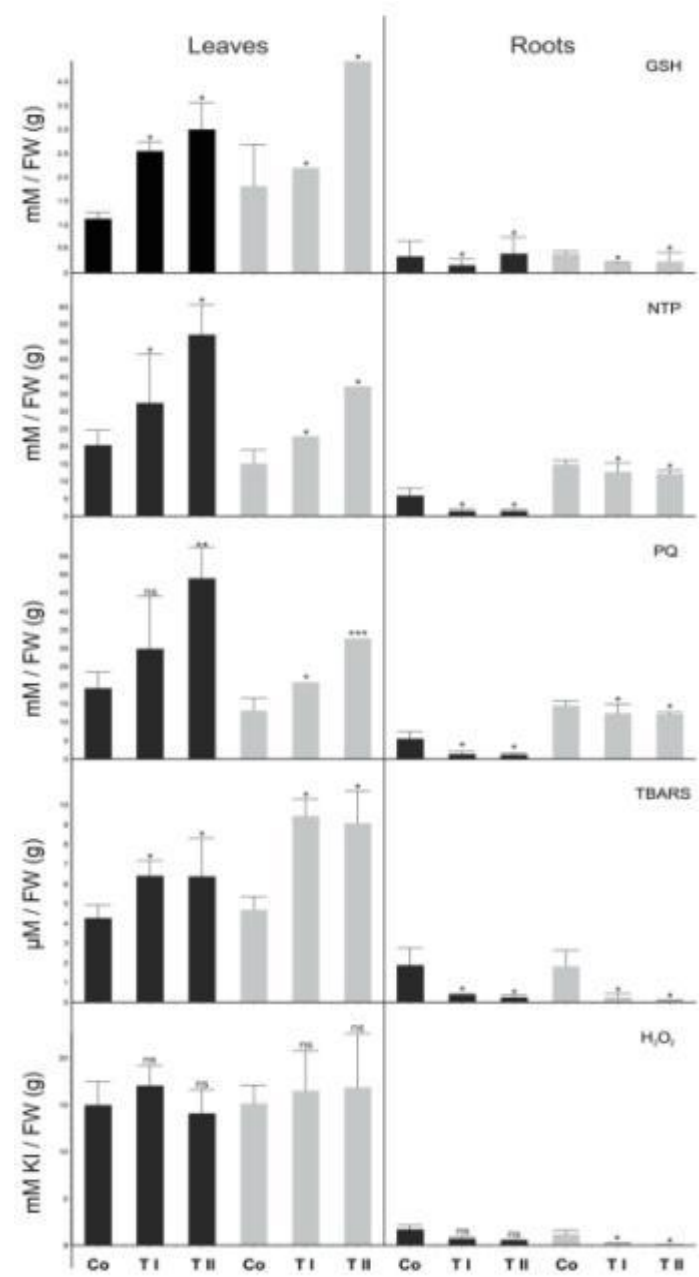

Fig. 3. Effects of Arsenic on antioxidant parameters as GSH, non-protein thiols, phytochelatins, and oxidant parameters as TBARS and $\mathrm{H}_{2} \mathrm{O}_{2}$ levels in leaves and roots of Glycine max. L

Mean values and standard error of mean (SEM), ${ }^{*} p<0.05,{ }^{* * *} p<0.001$ 
Marsa et al.; IJPSS, 8(1): 1-15, 2015; Article no.IJPSS.18979

Table 1. Genotoxicity of arsenic

\begin{tabular}{|c|c|c|c|c|c|c|c|c|c|c|}
\hline Genotoxicity & $\begin{array}{l}N^{\circ} \\
\text { cells }\end{array}$ & Prophase & Metaphase & Anaphase & Telophase & $\begin{array}{l}\text { Fragmented } \\
\text { nuclei }\end{array}$ & Micronuclei & $\begin{array}{l}\text { Binucleated } \\
\text { cells }\end{array}$ & $\begin{array}{l}\text { Disorganized } \\
\text { metaphase }\end{array}$ & $\begin{array}{l}\text { Mitotic } \\
\text { index (\%) }\end{array}$ \\
\hline Control 24 & 300 & 1 & 2 & & & & & & & 1 \\
\hline TI 24 & 300 & 2 & & & & & & & 1 & 1 \\
\hline TII 24 & 300 & 3 & & & & & & & & 1 \\
\hline Control 72 & 300 & 25 & 56 & 7 & 6 & & & & & 31.33 \\
\hline TI 72 & 300 & 12 & 3 & & & 1 & 1 & 1 & 1 & 5.33 \\
\hline TII 72 & 300 & 10 & & & & & & & & 1 \\
\hline
\end{tabular}




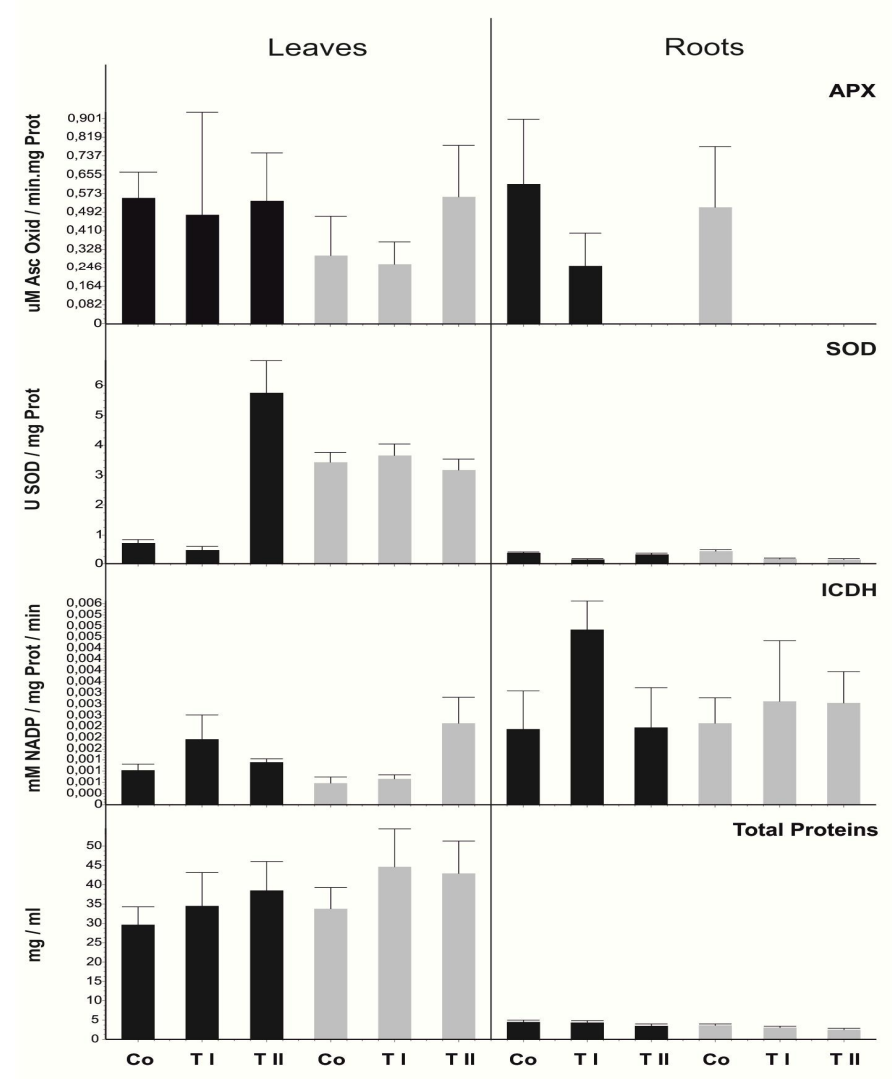

Fig. 4. Effect of Arsenic on total protein content ( $\mathrm{mg} / \mathrm{ml}$ ), APX, SOD and ICDH (U/mg protein) activities in leaves and roots

Mean values and standard error of mean (SEM), ${ }^{*} p<0.05,{ }^{* *} p<0.01,{ }^{* * *} p<0.001$
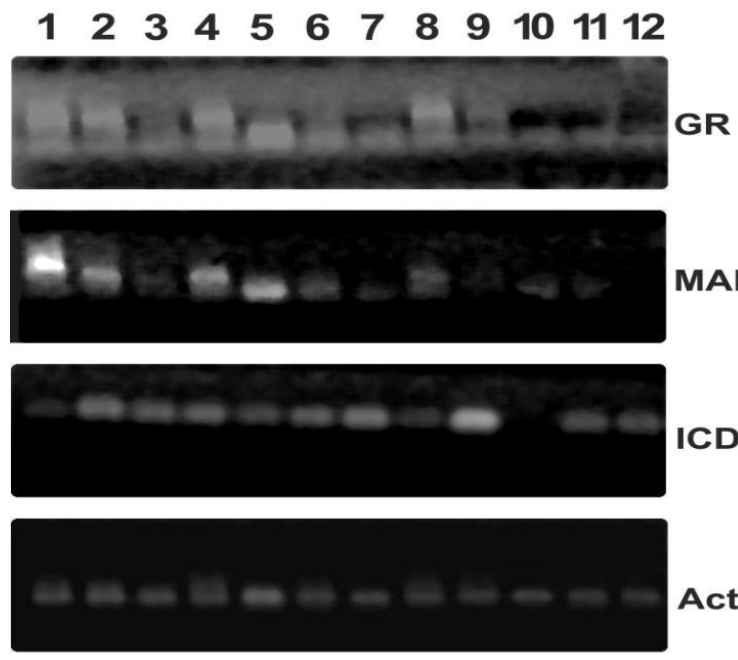

ICDH

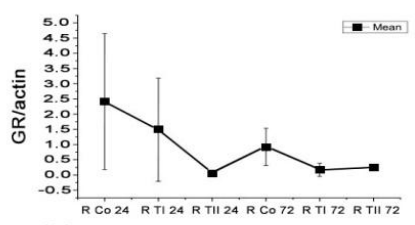

MAPK

Actin

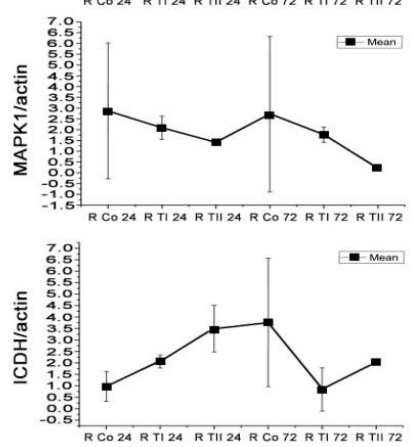

Fig. 5. Expression analysis of Glutathione reductase, Isocitrate dehydrogenase and MAPK under As treatment

Gene expression was determined by RT-PCR utilizing gene specific primer sets for each gene. Actin was used as internal control. (lines 1 and 2: roots of 24h control, 3 and 4 root TI 24h, 5-6-7: root TIl 24h, 8and 9: control 72h, 10 and 11: root $\mathrm{Tl} 72 \mathrm{~h}$ and 12 root $\mathrm{TIl} 72 \mathrm{~h}$ 


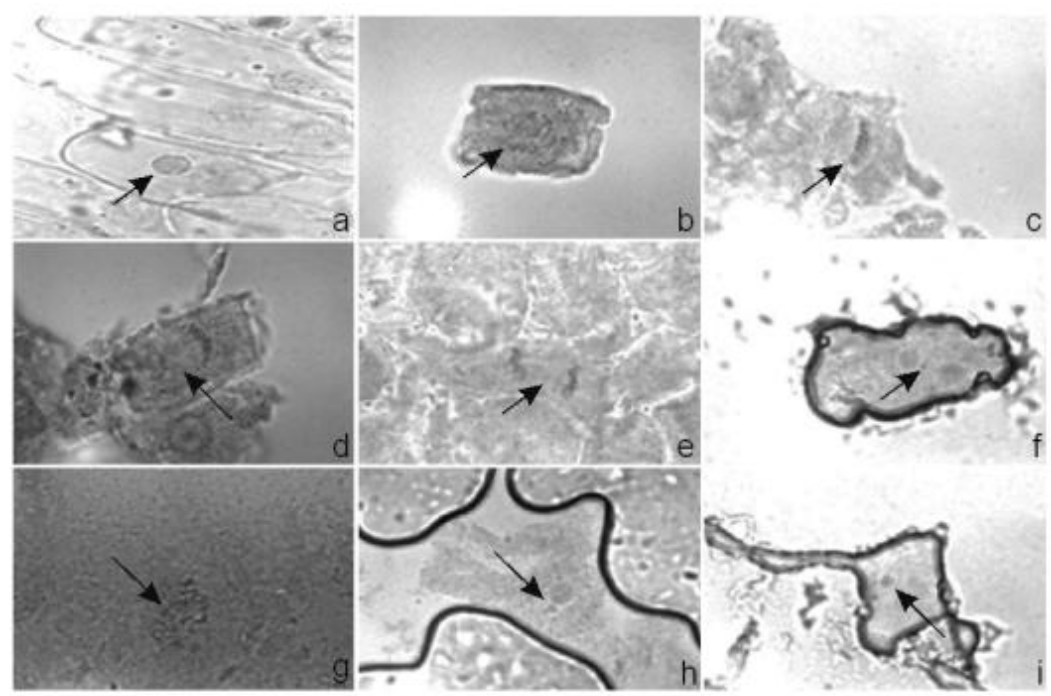

Photo 2. a) interphase Co, 24h; b) prophase at sample treated with 2,5ppm As (T I) at 24h; c) metaphase Co, $72 \mathrm{~h}$; d) anaphase treated sample with $5 \mathrm{ppm}$ As (TII) $72 \mathrm{~h}$; e) telophase treated sample with $2.5 \mathrm{ppm}$ As (TI) $72 \mathrm{~h}$; f) micronuclei treated sample $2.5 \mathrm{ppm}$ As (TI) $72 \mathrm{~h} ; \mathrm{g}$ ) disordered metaphase treated sample with $2.5 \mathrm{ppm}$ As 24 and $72 \mathrm{~h} ; \mathrm{h}$ ) binucleated cells and i) fragmented nuclei treated sample with $2.5 \mathrm{ppm}$ As $72 \mathrm{~h}$

The idea of using these As concentrations had two main objectives, first to measure the biochemical stress induced by As and analyze which are the optimal concentrations to induce this stress avoiding the plant enters into apoptosis. The determination of As in tissues of treated plants, showed that the same is incorporated into the roots and also the leaves, which is why one might assume that the soybean beans grown in contaminated soil may also contain heavy metal and thus constitute a new source of As input to the food and feed chain. Focusing on the experimental determination of As in leaves, it could be obtained several important facts, the first and perhaps most important, was the determination that our controls samples did not contain As and second, that in the treated samples As is present. These data allowed us to move forward with the rest of the experiments, as we ensured that the measured stress was due to the presence of metal in the tissues and not to an external factor. Morphological parameters in plants, as fresh weight and length, revealed that As induce major changes, similar results were obtained by Paivoke and Simola [38] and Duquesnoy [21]. Shri et al. [41] observed a decreased of fresh weight in rice plants with the presence of As, MDA increased, decreased length root, APX decreases with high concentrations of As and GSH decreased by its conversion to PCs. They observed that the leaves synthesize greater protein concentration than the roots, therefore enzyme activity in roots are markedly lower than those observed in the leaves. Therefore it must be analyzed in the treated groups with their respective controls to draw conclusions. The presence of heavy metals in higher plants is often accompanied by a variety of intracellular changes, some of which directly contribute to the sensitivity or tolerance of the plants to As. Similar observations have been made by Requejo and Tena [42]. Studies by Woolson et al. [43] reported a reduced growth of Phaseolus vulgaris plants, Phaseolus limensis (beans), Spinacia oleracea (spinach), Brassica oleracea (cabbage), Lycopersicum esculentum (tomato) and Raphanus sativus (radish) when exposed to various concentrations of arsenic added as sodium arsenate in the soil. Kiss et al. [44] observed a reduction in the value of the harvested crops of Oryza sativa (rice) from the addition of sodium arsenite at a concentration of As $50 \mathrm{mg} / \mathrm{kg}$ soil. In studies on the uptake, distribution and accumulation of arsenic in Brassica napus L. crops, Carbonell et al. [1] found that the exposure of plants to a nutrient solution with As (10 mg/l) - administered as sodium arsenite- damaged root membranes. Biochemical responses of plants to toxic metals are complex and, in this case, several defense strategies have been suggested. These include 
chelation of ions, reduced influx, and enhanced production of antioxidants that detoxify free radicals produced in response to them [6]. If the scavenging system of a plant does not cope well with the formation of free radicals or reactive oxygen species, uncontrolled oxidation and radical chain reactions are produced, which result in oxidative stress to the plant. Biochemical changes due to changes in antioxidant enzyme activities were observed by Duquesnoy et al. [21]. Total fresh weight is decreased only when the exposure is for $72 \mathrm{~h}$ due to dehydration of the leaves and marked decrease in the length of the stems. The biochemical changes observed in our experimental model, in the molecules that are generated by oxidative stress and molecules involved in antioxidant defense response are different in leaves respect to the root. While all of these parameters increased in leaves, those values decreased in roots with respect to the controls. With respect to the levels of MDA an increased at $24 \mathrm{~h}$ with respect to its control, was seen in leaves, but not in a significant way in any of the treatments $\mathrm{TI}$ and TII. At $72 \mathrm{~h}$ the levels of MDA increased very significantly. The analysis of these results show an induction of a strong lipid peroxidation, the results agree with those obtained by Gallego et al. [45,46], this is because much of the free radicals generated during the stress react with membrane lipids, especially those fatty acids containing double bonds, releasing MDA. In roots, a significant decreased at 24 and $72 \mathrm{~h}$ with $\mathrm{TI}$ and TII was observed, so we suggest that the $\mathrm{H}_{2} \mathrm{O}_{2}$ scavenged by CAT, decreases during senescence due to the decreased activity of SOD [47]. Glutathione reacts chemically with a wide range of ROS. The reduced coenzyme NADPH is a basic electron donor in many biosynthetic and detoxification reactions in living cells. NADPH is required for maintenance of the ascorbate-glutathione cycle, since it is necessary for the activity of GR, which recycles GSH from its oxidized form (GSSG) in order to be used for removing ROS [48]. The pair GSH / GSSG probably has more influence in controlling gene expression and protein function that the total size of the pool of GSH. So, like GSH, GSSG can initiate or enhance signaling cascades. The levels of reduced glutathione (GSH), in leaves increased in an extremely significance at 24 and $72 \mathrm{~h}$ with $\mathrm{TI}$ and TII. This increase is mainly due to glutathione is very active in front to oxidative stress as part of the ascorbate-glutathione cycle. Thus it is logical that GSH levels increase in conditions where activated oxygen species increase, in stress caused by the metal under study. These free radicals are recruited by the ascorbate (ASC) that is first oxidized to monodehydroascorbate (MDA) by APX and dehydroascorbate (DHA) is reduced to ASC by GSH by action of DHAR, and finally the reduction of GSSG to GSH in presence of NADPH and GR, closes the cycle mentioned above. On the other hand, GSH is the main precursor of phytochelatins (PCs), compounds that are synthesized by enzymes activated by heavy metals. In roots GSH levels fall with respect to their controls, in all the treatments. The non-protein thiols (NPT) and PCs in leaves and roots showed the same behavior that GSH. The biosynthesis of PCs plays a crucial role in the detoxification and homeostasis of As in plants [49]. Soybean plants showed a notably high contribution of GSH to the pool of thiols in shoots under arsenate exposure. We observed the same pattern of variation between NTPs, GSH and PCs: an increased level in leaves of plants treated with As. This increase was observed with greater intensity with increasing concentration of As and the exposure time. In contrast, the values of PCs and NTPs decreased with higher As concentration and the exposure time in the roots. The theoretical calculation of the contents of PCs proposed by Gallego et al. [45] indicates that the stress caused by As leads to the synthesis of the compound. This tendency of the samples that come in contact with As to a higher content of PCs was mainly due to the enzymes responsible for its synthesis are activated by the presence of various heavy metals, among it the As [4]. NAPD-ICDH activity is used in ascorbateglutathione cycle during senescence in leaves [50]. The changes we observed with this enzyme are due to the increasing concentrations of As that exceeded the enzymatic antioxidant defense system over the time. This enzyme is responsible for providing the reducing equivalents for the proper maintenance of the ascorbate-glutathione cycle [51,52]. We propose that in this type of extreme reduction equivalents necessarily have to come from other enzymes such as glucose-6phosphate dehydrogenase or any other dehydrogenases. APX with the coordinated action of catalase degraded $\mathrm{H}_{2} \mathrm{O}_{2}$, which could be involved in antioxidant processes by acting as a signal molecule. A significant decrease in SOD activity was observed in the leaves and roots of Z. mays with the majority of As treatments, [21]. An increase in the concentration of As increased APX activity in leaves and roots. We observed an increase in SOD activity only in leaves of soybean plants treated for $24 \mathrm{~h}$ with $5 \mathrm{ppm}$ of As, in other treatments we have not observed a 
significant difference. With other stresses such as the increased light intensity and low temperatures on two Dunaliella salina strains, showed a decrease of GSH and SOD activity [53]. In rice roots the PCs and the activity of MAPK increases because of the As effect, however, in our soybean crops under our experimental conditions we observed a decrease in gene expression for MAPK1 both at 24 and 72 $\mathrm{h}$ of treatment with As, and this decrease was greater with the increment of As concentration. We believe that oxidative stress parameters in the leaves increase because the activity of the cells of this organ is conserved; therefore, the enzymes synthesize the defense compounds and oxidative stress occur due to free radicals and other signaling molecules arriving from the root indicating the presence of As or a decrease in available $P$ [54]. This is supported by our results in the determination of total inorganic As, which is 200 times less in leaves than in the roots. In contrast, root cells are unable to produce defense molecules and carry out oxidative stress enzymatic reactions because the presence of As causes a decrease of $P$ that leads to a decrease in ATP. This decrease in ATP is responsible for the inability of the root cell to adequately perform the transcription processes of mRNA [55]. This is supported by our results obtained from RT-PCR assay of the enzymes responsible for synthesis of GSH, such as GR; a decrease in expression of genes involved in signals for programmed cell death such a MAPK is also observed, which means that cells lose responsiveness which leads to death. In contrast with other metals, the biochemical responses of plants to arsenic are not well understood. In some plant species, the arsenic-tolerance mechanisms are defined as suppression of the high- affinity phosphate arsenate uptake system $[6,56,57]$. In this study we observed that the synthesis has not been committed but there is a stimulation of many enzymes involved in defense against oxidative stress. In root that mechanism decreases due to the competition of As with $\mathrm{P}$, leading to a decrease of ATP and protein synthesis. This is consistent with the decrease of all enzymatic specific activities measured. [58]. Concomitant occurrence of genotoxicity and the generation of free radicals, indicate that reactive oxygen species may contributes to genotoxicity of As in soybean. The toxic effect of As is evidenced by an inhibition of root growth, it may involve reduction mechanisms of cell division kinetics. Deficiency in protein synthesis affects the formation of chromosomal proteins. [59].
Duquesnoy et al. [23] showed that high concentrations of As also caused a significant decrease in the mitotic index, and micronucleus chromosomal aberrations in the root meristems of both species: Zea mays and Vicia faba. Cotelle et al. [60] suggested that Ml effects can be considered as the initial mutagen impact of arsenic, leading to chromosomal abnormalities, such as micronuclei. For this reason, the changes in the $\mathrm{Ml}$ especially with the highest As concentration, could be due to inhibition of DNA synthesis or to blocking of the G2-phase as Patlolla et al. [61] and Mahoney et al. [62] showed in their studies.

\section{CONCLUSION}

On the basis of our results, we propose that leaves have an active antioxidant defense system, while roots accumulate arsenic as phytochelatins complexes and did not show oxidative stress because the signals like $\mathrm{H}_{2} \mathrm{O}_{2}$ are low. Although the observation of the nucleus demonstrated that the genotoxic effect of Arsenic has an effective impact on the soybean roots.

\section{ACKNOWLEDGEMENTS}

Authors are grateful to Lic. Emiliano Felici, Mr. Gerardo Randazzo, Arch. Alberto Daniel Hodara, and Mr. Ricardo Gómez for their technical assistance. We thank Vida L. Hodara PhD, from Southwest Foundation Biomedical Research P.O. Box 760549, San Antonio Texas, for her invaluable assistant in reviewing the manuscript. This work was supported by a grant from Universidad Nacional de San Luis, (2-0403 Proyect), and from CEFOBI (Centro de Estudios Fotosintéticos y Bioquímicos), Universidad Nacional de Rosario, Argentina.

\section{COMPETING INTERESTS}

Authors have declared that no competing interests exist.

\section{REFERENCES}

1. Carbonell-Barrachina AA, Burló F, López $E$, Martínez-Sánchez F. Arsenic toxicity and accumulation in radish as affected by arsenic chemical speciation. J Environ Sci Health B. 1999;34:661-679.

2. Tamaki S, Frankenberger WT. Environmental biochemistry of arsenic. Review of Environmental Contamination and Toxicology. 1992;124:79-110. 
3. Sneller FEC, Verkleij JAC. Toxicity of arsenate in Silene vulgaris, accumulation and degradation of arsenate-induced phytochelatins. New Phytologist. 1999;144: 223-232.

4. Schmoger MEV, Oven M, Grill E. Detoxification of arsenic by phytochelatins in plants. Plant Physiol. 2000;122:793-801.

5. Ullrich-Eberius $\mathrm{Cl}$, Novacky AJ. Evaluation of arsenate and vanadate-associated changes of electrical membrane potential and phosphate transport in Lemma gibba G1. Journal of Experimental Botany. 1989;40:119-128.

6. Meharg AA, Macnair MR. Phosphorusnutrition of arsenate-tolerant and nontolerant phenotypes of Velvetgrass. Journal of Environmental Quality. 1994;23: 234-238.

7. Srivastava S, Mishra S, Tripathi RD, Dwivedi S, Trivedi PK, Tandon PK. Phytochelatins and antioxidant systems respond differentially during arsenite and arsenate stress in Hydrilla verticillata (L.f.) Royle. Environ Sci Technol. 2007;41(8): 2930-2936.

8. Quaghebeur M, Rengel Z. The distribution of arsenate y arsenite in shoots and roots of Holcus lanatus is influenced by arsenic tolerance and arsenate and phosphate supply. Plant Physiology. 2003;132:16001609.

9. Gabrielli M, Sanita di Toppi L. Response to cadmium in higher plants. Environmental and Experimental Botany. 1999;41:105130.

10. Noctor G, Gomez L, Vanacker H, Foyer $\mathrm{CH}$. Antioxidants and Reactive Oxygen Species in Plants. J Exp Bot. 2002;53:1283-1304.

11. May MJ, Vernoux T, Leaver CJ, Montagu, Inzé D. Glutathione homeostasis in plants: Implications for environmental sensing and plant development. Journal of Experimental Botany. 1998;49:649-667.

12. Kerk NM, Feldman LJ. A biochemical model for the initiation and maintenance of the quiescent center: Implications for organization of root meristems. Development. 1995;121:2825-33.

13. Sanchez- Fernandez R, Fricker M, Corben LB, White NS, Sheard N, Leaver CJ, Van Montagu $M$, Inzé D, May MJ. Cell proliferation and hair tip growth in the Arabidopsis root are under mechanistically different forms of redox control.
Proceedings of the National Academy of Sciences. 1997;94:2745-50.

14. Muñoz-Solarte DM, Guerrero-Pepinosa N. Allium test para evaluar el efecto citotóxico y genotóxico de extractos naturales en células meristeméticas de Allium cepa. Memorias. 2013;11:83-86.

15. Donglin G, Jun M, Wenyue S, Baoming X, Changhong $G$. Contribution of reactive oxygen species (ROS) to genotoxicity of Nitrobenzene on $V$. faba. Ecotoxicology. 2014;23:657-664.

16. Smedley PL, Edmunds WM, Pelig-Ba KB. Mobility of arsenic in groundwater in the Obuasi gold-mining area of Ghana: Some implications for human health in: JD Appleton, R Fuge, GJH McCall (Eds.), Environmental Geochemistry and Health, Special Publication-Geological Society. 1996;113:163-181.

17. Benhusein G, Mutch E, Williams FM. Effect of arsenic on DNA damage, glutathione content, apoptosis and necrosis in HaCat cells. Toxicology. 2007;231:116-117.

18. Iwama S, Nakajo K, Aiuchi T, Nakaya K. Apoptosis induced by arsenic trioxide in leukemia U937 cells is dependent on activation of p38, inactivation of ERK and the $\mathrm{Ca} 2+$-dependent production of superoxide. International Journal of Canadian. 2001;92:518-526.

19. Ramirez T, García-Montalvo V, Wise C, Cea- Olivares R, Poirier LA, Herrera LA. Sadenosyl-L- methionine is able to reverse micronucleus formation induced by sodium arsenite and other cytoskeleton disrupting agents in cultured human cell. Mutation Research. 2003;528:61-74.

20. Shi H L, Hudson G, Ding W, Wang S, Cooper KL, Liu S, Chen Y, Shi X, Liu KJ. Arsenite causes DNA damage in keratinocytes via generation of hydroxyl radicals. Chemical Research in Toxicology. 2005;17:871-878.

21. Duquesnoy I, Champeau GM, Evray G, Ledoigt G, Piquet-Pissaloux A. Enzymatic adaptation to arsenic-induced oxidative stress in Zea mays and genotoxic effect of arsenic in roots tipos of Vicia fava and Zea mays. C.R. Biologies. 2010;333:814-824.

22. Hoagland DR, Arnon DI. The water culture method for growing plants without soil. California Agric. Exp. Stat. Univ. Calif. Berkeley Circ. 1953;347.

23. Suner MA, Devesa V, Munoz O, Lopez F, Montoro R, Arias AM, Blasco J. Total and inorganic arsenic in the fauna of the 
Guadalquivir estuary. Environmental and human health implications. Sci Total Environ. 1999;242:261-270.

24. Schupp R, Rennenberg H. Diurnal changes in the glutathione content of spruce needles (Picea abies L.). Plant Sci. 1988;57:113-117.

25. Anderson M. Determination of glutathione and glutathione disulfide in biological samples. Methods Enzymol. 1985;113: 545-548.

26. Ellman GL. Tissue sulfhydryl groups. Arch Biochem Biophys. 1959;82:70-77.

27. Schat $H$, Kalff $M$. Are phytochelatins involved in differential heavy metal tolerance or do they merely reflect metalimposed strain? Plant Physiology. 1992;99:1475-1480.

28. Sergiev I, Alexieva V, Karamov E. Effect of spermine, atrazine and combination between them on some endogenous protective systems and stress markers in plants. C R Acad. Bulg Sci. 1997;51:121124.

29. Heath RL, Packer L. Photoperoxidation in isolated chloroplasts: Kinetics and stoichiometry of fatty acid peroxidation. Arch. Biochem. Biophys. 1968;25:189-198.

30. Chen R, Le Marechal P, Vidal J, Gadal P. Purification and comparative properties of the cytosolic isocitrate dehydrogenases (NADP), from pea (Pisum sativum) roots and green leaves. Eur $\mathrm{J}$ Biochem. 1988;175:565-572.

31. Beyer WF, Fridovich Y. Assaying for superoxide dismutase activity: Some large consequences of minor changes in conditions. Anal. Biochem. 1987;161:559566.

32. Chen GX, Asada K. Ascorbate peroxidase in tea leaves: Occurrence of two isozymes and the differences in their enzymatic and molecular properties. Plant and Cell Physiology. 1989;30:987-998.

33. Bradford MM. A rapid and sensitive method for the quantitation of microgram quantities of protein utilizing the principle of protein-dye binding. Anal Biochem. 1976; 72:248-254.

34. Kobs G. Isolation of RNA from plant, yeast and bacteria. Promega Notes. 1998;68:2829.

35. Urteaga OF, Lallana V. Optimización de una técnica de tinción para determinación de efectos citogenéticos en ápices radicales de Allium Cepa. Revista Científica Agropecuaria. 2005;9:63-70.
36. Abedin MJ, Feldmann J, Meharg A. Uptake kinetics of Arsenic species in rice plants. Plant Physiology. 2002;128:1120-1128.

37. Burlo F, Guijarro I, Carbonell-Barrachina AA, Valero D, Martínez-Sánchez, $F$. Arsenic species: Effects on and accumulation by tomato plants. J Agric Food Chem. 1999;47:1247-1253.

38. Päivöke AE, Simola LK. Arsenate toxicity to Pisum sativum: Mineral nutrients, chlorophyll content, and phytase activity. Ecotoxicol Environ Saf. 2001;49:111-121.

39. Rosen BP. Biochemistry of arsenic detoxification. FEBS Lett. 2002;529:86-92.

40. González D, Ferrúa N, Cid J, Sansone G, Giménez I. Arsenic in ground waters of San Luis (Argentina). Use of an alternative equipment of modified Gutzeit. Acta Toxicol. Argent. 2003;11:3-6.

41. Shri M, Kumar S, Chakrabarty $P$, Kumar Trivedi P, Mallick S, Misra P, Shukla D, Mishra S, Srivastava S, Tripathi RD, Tuli R. Effect of arsenic on growth, oxidative stress, and antioxidant system in rice seedlings. Ecotoxicology and Environmental Safety. 2009;72:1102-1110.

42. Requejo $\mathrm{R}$, Tena $\mathrm{M}$. Maize response to acute arsenic toxicity as revealed by proteome analysis of plant shoots. Proteomics. 2006;6:156-162.

43. Woolson EA. Fate of arsenicals in different environmental substrates. Environ Health Perspect. 1977;19:73-81.

44. Kiss SA, Dombovári J, Oncsik M. Magnesium inhibits the harmful effects on plants of some toxic elements. Magnes Res. 1991;4:3-7.

45. Gallego SM, Benavides MP, Tomaro ML. Effect of heavy metal ion excess on sunflower leaves: Evidence for involvement of oxidative stress. Plant Science. 1996;121:151-159.

46. Gallego SM, Benavides MP, Tomaro ML. Effect of cadmium ions on antioxidant defense system in sunflower cotyledons. Biologia Plantarum. 1999;42:49-55.

47. Pastori GM, Del Rı LA. Natural senescence of pea leaves: An activated oxygen mediated function for peroxisomes. Plant Physiol. 1997;113:411-418.

48. Del Río LA. Reactive oxygen species, antioxidant systems and nitric oxide in peroxisomes. Journal of Experimental Botany. 2002;53:1-18. 
49. Vázquez S, Goldsbrough P, Carpena R. Comparative analysis of the contribution of phytochelatins to cadmium and arsenic tolerance in soybean and white lupin. Plant Physiology and Biochemistry. 2009;47:6367.

50. Corpas Francisco J, Barroso JB, Sandalio LM, Palma JM, Lupianez JA, del Río LA. Plant Physiology. 1999;121:921-928.

51. Corpas FJ, Sandalio LM, del Rio LA, Trelease RN. A deshydrogenase-mediated recycling system of NADPH in plant peroxisomes. Biochemical Journal. 1998; 330:777-84.

52. Valderrama R, Corpas FJ, Carreras A, Gomez-Rodriguez MV, Chaki M, Pedrajas $J R$, Fernandez-Ocaña A, del Río LA, Barroso J. The dehydrogenase-mediated recycling of NADPH is a key antioxidant system against salt- induced oxidative stress in olive plants. Plant, cell and Environment. 2006;29:1449-1459.

53. Haghjou MM, Shariati M, Smirnoff N. The effect of acute high light and low temperature stresses on the ascorbateglutathione cycle and superoxide dismutase activity in two Dunaliella salina strains. Physiol Plant. 2009;135:272-280.

54. Verbruggen $\mathrm{N}$, Hermans $\mathrm{C}$, Schat $\mathrm{H}$. Molecular mechanisms of metal hyperaccumulation in plants. New Phytol. 2009;181:759-776.

55. Zhao FJ, Stroud JL, Eagling T, Dunham SJ, McGrath SP, Shewry PR. Accumulation, distribution, and speciation of arsenic in wheat grain. Environ Sci Technol. 2010;44:5464-5468.
56. Hartley-Whitaker J, Ainsworth G, Meharg AA. Copper and arsenate-induced oxidative stress in Holcus lanatus L. clones with differential sensitivity. Plant Cell Environ. 2001;24:713-722.

57. Tu S, Ma LQ. Comparison of arsenic uptake and distribution in arsenic hyperaccumulator Pteris vittata and nonhyperaccumulator Nephrolepis exaltata. Journal of Plant Nutrition. 2004;27:12271242.

58. Funatsuki $\mathrm{H}$, Kurosaki $\mathrm{H}$, Murakami $\mathrm{T}$, Matsuba S, Kawaguchi K, Yumoto S, Sato Y. Deficiency of a cytosolic ascorbate peroxidase associated with chilling tolerance in soybean. Theor Appl Genet. 2003;06:494-502.

59. Andrioli N, Wulff A, Mudry M. Allium Cepa como biomonitor de toxicidad y genotoxicidad de metronidazol. Theoria. 2006;15:9-16.

60. Cotelle S, Masfaraud JF, Ferard JF. Assessment of the genotoxicity of contaminated soil with the Allium/ Viciamicronucleus and the Trad-escaniamicronucleus assays. Mutation Research. 1999; 426:167-171.

61. Patlolla AK, Tchounwou BP. Cytogenetic evaluation of arsenic trioxide toxicity in Sprague-dawley rats. Mutation Research. 2005;587:126-133.

62. Mahoney NM, Gohta G, Douglass AD, Vale Making RD. Microtubules and mitotic spindles in cells without functional centrosomes. Current Biology. 2006;16: 564-569.

(c) 2015 Marsa et al.; This is an Open Access article distributed under the terms of the Creative Commons Attribution License (http://creativecommons.org/licenses/by/4.0), which permits unrestricted use, distribution, and reproduction in any medium, provided the original work is properly cited.

Peer-review history:

The peer review history for this paper can be accessed here: http://sciencedomain.org/review-history/10034 